Jurnal Health Sains: p-ISSN:2723-4339 e-ISSN: 2548-1398

Vol. 2, No. 4, April 2021

\title{
FAKTOR-FAKTOR YANG BERHUBUNGAN DENGAN PENGETAHUAN PENGGUNAAN SUNSCREEN PADA MAHASISWA UNIVERSITAS TADULAKO
}

\section{Nurfitriani, Amelia Rumi dan Asriana Sultan}

Universitas Tadulako, Sulawesi Tengah, Indonesia

Email: nurfitrianilagoda@gmail.com, amelia.rumi@ gmail.com dan srianasultan@ gmail.com

\begin{tabular}{|c|c|}
\hline ARTIKEL INFO & ABSTRACT \\
\hline $\begin{array}{l}\text { Tanggal diterima: } 5 \text { April } 2021 \\
\text { Tanggal revisi: } 15 \text { April } 2021 \\
\text { Tanggal yang disetujui: } 25 \\
\text { April } 2021\end{array}$ & $\begin{array}{l}\text { Sunscreen compound is an ingredient used to protect the } \\
\text { skin from exposure to sunlight, especially ultraviolet }(U V) \text {. } \\
\text { This compound is one of the chemicals in liquid lotions that } \\
\text { penetrate into the skin and will absorb UV radiation before }\end{array}$ \\
\hline $\begin{array}{l}\text { Keywords: } \\
\text { Sunscreen; level of knowledge; } \\
\text { Tadulako University students }\end{array}$ & $\begin{array}{l}\text { it reaches the skin layer. This study aims to find out the } \\
\text { level of knowledge of Tadulako University students about } \\
\text { the use of sunscreen products and factors related to the use } \\
\text { of such products. This study is a non-experimental } \\
\text { (observational) study using a cross sectional approach with } \\
\text { the number of respondents } 430 \text { people where } 396 \text { meet the } \\
\text { criteria and } 34 \text { do not meet the criteria in this study. } \\
\text { Sampling techniques are purposive sampling using } \\
\text { questionnaires. The results of the data processing showed } \\
\text { the level of knowledge of tadulako university students, } \\
\text { based on the average percentage of correct answers, } \\
\text { categorized both at } 82.2 \% \text { and based on age, gender and } \\
\text { force categorized quite } 74.2 \% \text {. Factors related to sunscreen } \\
\text { use are gender with a p-value of } 0.008<0.05 \text { which means } \\
\text { there is a relationship between gender and knowledge level. }\end{array}$ \\
\hline
\end{tabular}

\begin{abstract}
ABSTRAK
Senyawa sunscreen merupakan suatu bahan yang digunakan untuk melindungi kulit dari paparan sinar matahari terutama ultraviolet (UV). Senyawa ini merupakan salah satu bahan kimia dalam lotion cair yang berpenetrasi ke dalam kulit dan akan menyerap radiasi UV sebelum mencapai lapisan kulit. Penelitian ini bertujuan untuk mengetahui tingkat pengetahuan mahasiswa Universitas Tadulako tentang penggunaan produk sunscreen dan faktor-faktor yang berhubungan dengan penggunaan produk tersebut. Penelitian ini merupakan penelitian non-eksperimental (observasional) menggunakan pendekatan cross sectional (potong lintang) dengan jumlah responden 430 orang dimana 396 memenuhi kriteria dan 34 tidak memenuhi kriteria pada penelitian ini. Teknik pengambilan sampel yaitu secara purposive sampling menggunakan kuesioner. Hasil pengolahan data menunjukkan tingkat pengetahuan mahasiswa Universitas Tadulako, berdasarkan rata-rata persentase jawaban benar, dikategorikan baik yaitu $82,2 \%$
\end{abstract}


Kata Kunci:

Sunscreen; tingkat pengetahuan; mahasiswa Universitas

Tadulako dan berdasarkan usia, jenis kelamin dan angkatan dikategorikan cukup yaitu $74,2 \%$. Faktor-faktor yang berhubungan dengan penggunaan sunscreen adalah jenis kelamin dengan nilai p-value $0,008<0,05$ yang berarti ada hubungan antara jenis kelamin dengan tingkat pengetahuan.

\section{Pendahuluan}

Sunscreen merupakan senyawa yang digunakan untuk melindungi kulit dari sinar matahari terutama sinar ultraviolet (UV). Sunscreen ini termasuk cairan kimia lotion yang dapat digunakan sebagai tabir surya. sunscreen dapat menembus kulit dan menyerap sinar ultraviolet sebelum mencapai lapisan kulit dan menyebabkan kerusakan pada kulit (Pratiwi et al., 2017).

Salah satu cara untuk mencegah efek berbahaya dari paparan sinar matahari pada kulit adalah dengan menggunakan sunscreen. Mekanisme kerja sunscreen adalah memantulkan sinar ultraviolet (UV), dan menyerap sinar ultraviolet, karena sifat fisiknya yang mencegah sinar ultraviolet menembus lapisan kulit dengan cara menyebarkannya, kemampuannya berdasarka $\mathrm{n}$ ukuran partikel dan ketebalan lapisan dermis hingga ke subkutan, dan efektif dalam spektrum UV-A, UV-B dan sinar tampak (Rosyidi et al., 2018).

Sinar ultraviolet (UV-B) mendekati $300 \mathrm{~nm}$ dapat menembus stratum korneum dengan baik dan menyebabkan luka bakar epidermal yang parah (eritema), terutama pada orang kulit putih. Radiasi dengan panjang gelombang lebih dari $350 \mathrm{~nm}$ mulai menembus dermis, merangsang pembentukan melanin, dan menyebabkan pencoklatan kulit (tanning) akibat paparan sinar matahari. Meskipun energi sinar UV-A lebih rendah daripada UV-B, pada kenyataannya sinar UVA dapat menembus lebih jauh kedalam jaringan subkutan, yang dapat menyebabkan deformasi elastic dan kerusakan kulit yang menyebabkan kanker kulit (Suaskara.M.Si, 2016).

Sun Protection Factor (SPF) merupakan indikator umum yang dapat menjelaskan efektifitas suatu produk atau zat sebagai pelindung UV. Semakin tinggi nilai SPF suatu produk atau tabir surya aktif maka semakin efektif dapat melindungi kulit dari zat berbahaya sinar ultraviolet (Kementrian Kesehatan Republik Indonesia, 2014).

Pengetahuan adalah bidang yang sangat penting dimana perilaku seseorang dibentuk. Pengetahuan yang baik dapat menghasilkan sikap pribadi yang baik. Banyak faktor yang mempengaruhi pengetahuan seseorang, salah satunya adalah tingkat pendidikan (Gontor, 2016)

Berdasarkan penelitian (Wadoe, 2015) tingkat pengetahuan mahasiswa Universitas Airlangga dalam menggunakan sunscreen berasal dari 130 responden, 7 responden berpengetahuan kurang, 13 responden berpengetahuan baik, dan sebanyak 110 responden berpengetahuan sedang. Rata-rata pengetahuan responden tentang sunscreen dari 130 responden adalah 7,3 jauh dibawah rata-rata 32 yang merupakan tingkat pengetahuan tertinggi dalam survey ini. Dari 130 responden, sebanyak 53 responden memiliki tingkat pengetahuan di atas rata-rata, sedangkan 67 responden memiliki tingkat pengetahuan dibawah rata-rata.

Berdasarkan penelitian yang telah dilakukan oleh (Mumtazah et al., 2020) didapatkan data demografi responden yaitu usia, jenis kelamin dan tingkat semester. Diantara responden, sebanyak 136 laki-laki $(64,8 \%)$ dan 74 perempuan $(35,2 \%)$ dari penelitian ini terlihat bahwa pengetahuan responden yang kurang terlihat dari jawaban benar yang rendah untuk beberapa pertanyaan, seperti jenis sinar ultraviolet, waktu menghindari paparan sinar matahari, 
pengertian SPF 30, cara membersihkan sunscreen dan minimal SPF yang digunakan setiap hari.

Berdasarkan penelitian yang telah dilakukan oleh (Rossy Ardhia Pramesti, 2019) hasil penelitian yang didapatkan menunjukkan bahwa sebanyak $80,0 \%$ responden laki-laki memiliki tingkat pengetahuan yang baik, dan sebanyak $91,5 \%$ responden perempuan memiliki tingkat pengetahuan yang baik, maka dapat disimpulkan bahwa sebagian besar responden memiliki tingkat pengetahuan yang baik. Berdasarkan perbandingan hasil persentase yang terdapat pada tabel penelitian ini, perempuan memiliki tingkat pengetahuan yang lebih tinggi dibandingkan laki-laki.

Menurut (Mumtazah et al., 2020) perilaku penggunaan sunscreen oleh mahasiswa Palestina menunjukkan bahwa dari 250 responden, hanya $118(47,2 \%)$ yang telah menggunakan sunscreen, sedangkan tingkat penggunaan sunscreen untuk pria hanya sekitar $14,4 \%$. Hal ini menunjukkan masih minimnya pengetahuan mahasiswa tentang sunscreen. Umumnya, paparan sinar UV pada mahasiswa setiap harinya yaitu $10-70 \%$ tergantung lama paparan.

Berdasarkan survey penelitian ini pada mahasiswa Universitas Tadulako masih kurangnya kesadaran pada mahasiswa tentang pentingnya melindungi kulit dari sinar matahari, dimana masih banyaknya mahasiswa yang menggunakan pakaian lengan pendek, dengan alasan suasana yang panas apalagi pada mahasiswa yang berjenis kelamin laki-laki (Isabela, 2010). Pada penelitian ini peneliti tertarik mengetahui penggunaan sunscreen karena berdasarkan survey rata-rata mahasiswa Universitas Tadulako menggunakan sunscreen dibandingkan dengan sunblok. Hal inilah yang melatarbelakangi penelitian faktor-faktor yang berhubungan dengan pengetahuan penggunaan sunscreen pada mahasiswa Universitas Tadulako.
Berdasarkan penelitian yang telah dilakukan ditemukan hasil yang berbeda pada penelitian sebelumnya dimana tingkat pengetahuan mahasiswa universitas tadulako memiliki pengetahuan baik mengenai penggunaan sunscreen jika dilihat dari jumlah jawaban kuesioner dan memiliki pengetahuan cukup jika dilihat dari segi usia, jenis kelamin dan angkatan. Hal ini disebabkan karena perbedaan sampel pada tiap penelitian yang digunakan sehingga dapat menghasilkan tingkat pengetahuan yang berbeda pada tiap populasi penelitian. Adapun faktor-faktor yang mempengaruhi pengetahuan diantaranya usia, pendidikan, lingkungan, pengalaman serta informasi yang didapatkan oleh responden penelitian.

\section{Metode Penelitian}

Penelitian ini telah dinyatakan sesuai dengan prinsip-prinsip etika penelitian oleh Komite Etik Penelitian Fakultas Kedokteran Universitas Tadulako dengan dikeluarkannya Surat Pernyataan Komite Etik dengan nomor: 8174/UN 28.1.30/KL/2020.

Penelitian ini adalah penelitian noneksperimental (observasional), dengan pendekatan metode cross sectional (potong lintang) dimana responden pada penelitian ini yaitu mahasiswa Universitas Tadulako dengan mengisi kuesioner melalui google form yang berisi pertanyaan seputar data demografi, pengetahuan penggunaan tentang sunscreen. Kemudian setelah data terkumpul, dilakukan analisis chi-square (Notoatmodjo, 2012) menggunakan bantuan sistem program SPSS (statistical product and service solutions) yang digunakan untuk melihat faktor-faktor yang berhubungan dengan pengetahuan penggunaan sunscreen pada mahasiswa Universitas Tadulako.

Penelitian ini dilakukan pada bulan Oktober 2020 bertempat di Universitas Tadulako Jl. Soekarno Hatta, KM. 9, Tondo, Mantikulore, Kota Palu, Sulawesi Tengah. Teknik pengambilan sampel purposive 
Faktor-Faktor yang Berhubungan dengan Pengetahuan Penggunaan Sunscreen pada Mahasiswa

sampling yaitu semua mahasiswa yang memenuhi kriteria inklusi dan eksklusi.

Validitas adalah uji untuk setiap variabel masalah. Jika pertanyaan dalam kuesioner dapat mengungkapkan apa yang akan diukur dengan kuesioner tersebut, maka kuesioner tersebut dianggap valid (Muda, 2014). Reliabilitas merupakan indicator Uji reliabilitas menggunakan SPSS dimana seluruh pertanyaan yang valid di uji reliabilitasnya dikatakan reliabel apabila nilai Cronbach's Alpha minimal 0.6.

\section{Hasil dan Pembahasan}

\section{a. Uji Validitas}

\begin{tabular}{|c|c|c|c|}
\hline Pertanyaan & r hitung & $\begin{array}{c}\mathbf{r} \\
\text { tabel }\end{array}$ & Keterangan \\
\hline P1 & a & 0,361 & Valid \\
\hline $\mathrm{P} 2$ & $a^{a}$ & 0,361 & Valid \\
\hline P3 & 0,561 & 0,361 & Valid \\
\hline $\mathrm{P} 4$ & $a^{a}$ & 0,361 & Valid \\
\hline P5 & 0,528 & 0,361 & Valid \\
\hline P6 & 0,393 & 0,361 & Valid \\
\hline P7 & 0,375 & 0,361 & Valid \\
\hline P8 & 0,713 & 0,361 & Valid \\
\hline P9 & 0,528 & 0,361 & Valid \\
\hline P10 & 0,622 & 0,361 & Valid \\
\hline P11 & 0,612 & 0,361 & Valid \\
\hline $\mathrm{P} 12$ & 0,405 & 0,361 & Valid \\
\hline P13 & 0,363 & 0,361 & Valid \\
\hline P14 &.$^{a}$ & 0,361 & Valid \\
\hline $\mathrm{P} 15$ & 0,535 & 0,361 & Valid \\
\hline P16 & ${ }^{a}$ & 0,361 & Valid \\
\hline $\mathrm{P} 17$ & 0,561 & 0,361 & Valid \\
\hline P18 & $\mathrm{a}$ & 0,361 & Valid \\
\hline P19 & 0,561 & 0,361 & Valid \\
\hline $\mathrm{P} 20$ & $a^{a}$ & 0,361 & Valid \\
\hline
\end{tabular}

Pengujian menggunakan software SPSS versi 24 dengan jumlah sampel $(\mathrm{n})=$ 30 responden sehingga didapatkan nilai $r$ tabel sebesar 0,361. Uji validitas yang telah dilakukan didapatkan hasil pertanyaan yang valid berjumlah 20 pertanyaan dari 30 pertanyaan dengan menggunakan 30 responden. Dikatakan valid apabila $r$ hitung $>r$ tabel. b. Uji Reliablitas

\begin{tabular}{cc}
\hline Cronbach's Alpha & N of Items \\
\hline 0.707 & 23 \\
\hline
\end{tabular}

Menurut (Ignas, 2014) uji reliabilitas digunakan untuk mengukur kestabilan dan konsistensi jawaban responden terhadap masing-masing variabel yang ada dalam kuesioner. Uji reliabilitas dilakukan menggunakan aplikasi SPSS dengan jumlah sampel uji sebanyak 396. Hasil uji reliabilitas pengetahuan terhadap 396 responden didapatkan hasil koefisien alpha pengetahuan adalah 0,707 yang berarti reliabel.

c. Sampel

1. Jumlah responden mahasiswa Universitas Tadulako

\begin{tabular}{cc}
\hline $\begin{array}{l}\text { Responden mahasiswa Universitas Tadulako } \\
\text { angkatan 2019, 2018, 2017, 2016, 2015 dan 2014 }\end{array}$ & $\begin{array}{c}\text { Jumlah } \\
\text { Responden }\end{array}$ \\
\hline Memenuhi Kriteria & 396 \\
Tidak Memenuhi Kriteria & 34 \\
\hline Total & 430 \\
\hline
\end{tabular}

Dari hasil pengumpulan data yang dilakukan melalui google form pada mahasiswa Universitas Tadulako angkatan 2019, 2018, 2017, 2016, 2015 dan 2014 didapatkan responden berjumlah 430 orang. Jumlah responden yang memenuhi kriteria inklusi sebanyak 396 dan yang memenuhi kriteria ekslusi berjumlah 34 orang dikarenakan responden yang mengisi kuesioner di google form tidak mengisi kuesioner dengan lengkap dan bukan mahasiswa Universitas Tadulako.

d. Dekskripsi responden mahasiswa Universitas Tadulako angkatan 2014, 2015, 2016, 2017, 2018, dan 2019

\begin{tabular}{|c|c|c|c|}
\hline Variabel & Kategori & $\begin{array}{c}\text { Jumlah } \\
\text { Responden } \\
(\mathrm{n}=396)\end{array}$ & $\begin{array}{c}\text { Persentase } \\
(\%)\end{array}$ \\
\hline \multirow{4}{*}{ Usia } & $\begin{array}{l}18-20 \\
\text { tahun }\end{array}$ & 187 & 47,2 \\
\hline & $\begin{array}{l}21-23 \\
\text { tahun }\end{array}$ & 207 & 52,3 \\
\hline & $\begin{array}{l}24-26 \\
\text { tahun }\end{array}$ & 2 & 0,5 \\
\hline & Total & 396 & 100 \\
\hline
\end{tabular}




\begin{tabular}{|c|c|c|c|}
\hline \multirow[t]{3}{*}{ Jenis Kelamin } & Laki-Laki & 111 & 28,0 \\
\hline & Perempuan & 285 & 72,0 \\
\hline & Total & 396 & 100 \\
\hline \multirow{7}{*}{ Angkatan } & $\begin{array}{c}\text { Tahun } \\
2014 \\
\end{array}$ & 9 & 2,3 \\
\hline & $\begin{array}{l}\text { Tahun } \\
2015\end{array}$ & 16 & 4,0 \\
\hline & $\begin{array}{c}\text { Tahun } \\
2016\end{array}$ & 35 & 8,8 \\
\hline & $\begin{array}{l}\text { Tahun } \\
2017\end{array}$ & 175 & 44,2 \\
\hline & $\begin{array}{c}\text { Tahun } \\
2018\end{array}$ & 79 & 19,9 \\
\hline & $\begin{array}{l}\text { Tahun } \\
2019\end{array}$ & 82 & 20,7 \\
\hline & Total & 396 & 100 \\
\hline
\end{tabular}

Pada uraian ini akan dijelaskan karakteristik pada 396 responden berupa usia, jenis kelamin, dan angkatan. Pada tabel 4.3 dijelaskan bahwa berdasarkan kategori usia responden 18-20 sebanyak 187 orang $(47,2 \%)$, usia $21-23$ sebanyak 207 orang $(52,3 \%)$, dan usia 24-26 sebanyak 2 orang $(0,5 \%)$. Berdasarkan kategori jenis kelamin, responden lakilaki sebanyak 111 orang $(28,0 \%)$, sedangkan responden perempuan sebanyak 285 orang (72,0\%). Berdasarkan kategori angkatan, responden angkatan 2014 sebanyak 9 orang (2,3\%), angkatan 2015 sebanyak 16 orang (4,0\%), angkatan 2016 sebanyak 35 orang $(8,8 \%)$, angkatan 2017 sebanyak 175 orang (44,2\%), angkatan 2018 sebanyak 79 orang (19,9\%), dan angkatan 2019 sebanyak 82 orang $(20,7 \%)$.

\section{e. Deskripsi tingkat pengetahuan}

1. Berdasarkan usia mahasiswa

\begin{tabular}{|c|c|c|c|c|}
\hline \multirow[t]{2}{*}{ Usia (tahun) } & \multicolumn{3}{|c|}{$\begin{array}{c}\text { Pengetahuan penggunaan } \\
\text { sunscreen berdasarkan } \\
\text { kategori }\end{array}$} & \multirow[t]{2}{*}{$\begin{array}{c}\text { Total } \\
\text { Responden } \\
(\%)\end{array}$} \\
\hline & $\begin{array}{l}\text { Kurang } \\
(<56 \%)\end{array}$ & $\begin{array}{r}\text { Cukup } \\
(56- \\
75 \%) \\
\end{array}$ & $\begin{array}{l}\text { Baik } \\
(76-100 \%\end{array}$ & \\
\hline $18-20$ & 0 & 133 & 54 & $\begin{array}{c}187 \\
(47.2 \%)\end{array}$ \\
\hline $21-23$ & 2 & 159 & 46 & $\begin{array}{c}207 \\
(52.2 \%)\end{array}$ \\
\hline $24-26$ & 0 & 2 & 0 & $2(0.5 \%)$ \\
\hline Total & 2 & 294 & 100 & $\begin{array}{c}396 \\
(100 \%)\end{array}$ \\
\hline
\end{tabular}

Berdasarkan tabel tersebut didapatkan hasil yang memiliki pengetahuan cukup dengan kategori usia 21-23 sebanyak 159 orang, usia 18-20 sebanyak 133 orang dan usia 2426 sebanyak 2 orang. Hal ini dapat terjadi karena pada usia 21-23 seseorang telah memahami tentang sunscreen dan semakin bertambah usia seseorang, semkain berkembang persepsi dan pola pikirnya, yang akan membuat ilmu yang diperoleh menjadi lebih baik (Mubarak, 2011), dan pada usia tersebut memiliki jumlah responden terbanyak yaitu 207 orang, pada usia 18-20 daya tangkap seseorang akan lebih berkembang sehingga telah mengetahui tentang sunscreen dan menjawab pertanyaan kuesioner dengan tepat sedangkan pada usia 24-26 untuk pengetahuan mengenai sunscreen hanya 2 orang yang masuk dalam kategori cukup, hal ini dapat terjadi karena responden pada usia tersebut hanya 2 orang. Untuk kategori kurang pada usia 21-23 sebanyak 2 orang yang memiliki pengetahuan kurang, hal ini dapat terjadi karena dari 207 orang sebanyak 2 orang masih kurang memahami tentang penggunaan sunscreen dapat diketahui dari jawaban responden pada kuesioner yang diberikan. Sedangkan pada usia 18-20 dan 24-26 sebanyak 0 orang yang memiliki pengetahuan kurang, hal ini dapat terjadi karena pada usia tersebut seseorang telah mengetahui tentang penggunaan sunscreen. Untuk kategori baik pada usia 18-20 sebanyak 54 orang yang memiliki pengetahuan baik, hal ini dapat terjadi karena berdasarkan pertanyaan kuesioner seseorang telah memahami tentang sunscreen dan semakin bertambah usia pola pikir lebih berkembang sehingga pengetahuan yang dimiliki seseorang lebih baik. Usia 
21-23 sebanyak 46 orang yang berpengetahuan baik, hal ini juga dapat terjadi karena seseorang telah memahami tentang sunscreen dan lebih sering mencari informasi mengenai sunscreen baik melalui media sosial maupun pengetahuan yang dimilikinya sehingga pada kuesioner yang diberikan responden mampu menjawab pertanyaan dengan tepat. Sedangkan pada usia 24-26 sebanyak 0 orang yang berpengetahuan baik, hal ini dapat diketahui dari jawaban responden pada kuesioner yang diberikan masih kurang menjawab pertanyaan dengan tepat sehingga pengetahuan pada usia 24-26 tidak termasuk dalam kategori baik dan pada usia tersebut memiliki jumlah responden paling sedikit sebanyak 2 orang.

2. Berdasarkan jenis kelamin mahasiswa

\begin{tabular}{ccccc}
\hline $\begin{array}{c}\text { Jenis } \\
\text { Kelamin }\end{array}$ & \multicolumn{2}{c}{$\begin{array}{c}\text { Pengetahuan penggunaan } \\
\text { sunscreen berdasarkan kategori }\end{array}$} & $\begin{array}{c}\text { Total } \\
\text { Responden } \\
(\%)\end{array}$ \\
\hline & $\begin{array}{c}\text { Kurang } \\
(<56 \%)\end{array}$ & $\begin{array}{c}\text { Cukup } \\
(56-75 \%)\end{array}$ & $\begin{array}{c}\text { Baik } \\
(\mathbf{7 6 -} \\
100 \%)\end{array}$ & \\
\hline Laki-Laki & $\mathbf{2}$ & $\mathbf{7 3}$ & $\mathbf{3 6}$ & $\mathbf{1 1 1 ( 2 8 \% )}$ \\
\hline Perempuan & $\mathbf{0}$ & $\mathbf{2 2 1}$ & $\mathbf{6 4}$ & $\mathbf{2 8 5}(\mathbf{7 2 \%})$ \\
\hline Total & 2 & 294 & 100 & $\begin{array}{c}396 \\
(100 \%)\end{array}$ \\
\cline { 5 - 5 } & & & &
\end{tabular}

Berdasarkan Tabel diatas jenis kelamin perempuan memiliki pengetahuan cukup sebanyak 221 orang dibandingkan laki-laki sebanyak 73 orang. Hal ini dapat terjadi karena yang berjenis kelamin perempuan lebih sering mencari tahu informasi mengenai sunscreen melalui media sosial dan lebih sering menggunakan produk sunscreen sehingga lebih mengetahui tentang sunscreen. Oleh karena itu responden perempuan mampu menjawab pertanyaan dengan tepat. Sedangkan yang berjenis kelamin lakilaki dari 111 orang hanya 73 orang yang memiliki pengetahuan kurang, hal ini dapat terjadi karena laki-laki jarang mencari tahu informasi mengenai sunscreen dan kepribadian yang dimiliki yang kurang memperhatikan kondisi kulit. Untuk kategori kurang mahasiswa yang berjenis kelamin lakilaki memiliki pengetahuan kurang sebanyak 2 orang dari 111 orang, hal ini dapat terjadi karena berdasarkan pertanyaan kuesioner sebanyak 2 orang yang kurang menjawab dengan tepat karena kurang mencari tahu tentang sunscreen, Sedangkan yang berjenis kelamin perempuan sebanyak 0 orang yang berpengetahuan kurang, hal ini dapat terjadi karena perempuan telah mengetahui tentang sunscreen karena lebih sering mencari tahu tentang sunscreen dan sering menggunakan produk sunscreen. Untuk kategori baik mahasiswa yang berjenis kelamin lakilaki dari 111 orang hanya 36 orang yang berpengetahuan baik, hal ini terjadi karena sebanyak 36 orang telah mengetahui tentang sunscreen dapat diketahui dari jawaban responden pada kuesioner yang diberikan, dimana sebanyak 36 orang menjawab pertanyaan dengan tepat sehingga memiliki pengetahuan yang baik. Sedangkan mahasiswa yang berjenis kelamin perempuan dari 285 orang sebanyak 64 orang berpengetahuan baik, hal ini dapat terjadi karena lebih sering mencari tahu tentang sunscreen dan menggunakan produk sunscreen sehingga pengetahuan yang dimiliki lebih baik lagi.

3. Berdasarkan angkatan mahasiswa

\begin{tabular}{ccccc}
\hline ngkatan & A & $\begin{array}{c}\text { Pengetahuan penggunaan sunscreen } \\
\text { berdasarkan kategori }\end{array}$ & $\begin{array}{c}\text { Total } \\
\text { Responden } \\
(\%)\end{array}$ \\
\hline & $\begin{array}{c}\text { Kurang } \\
(<56 \%)\end{array}$ & $\begin{array}{c}\text { Cukup } \\
(56-75 \%)\end{array}$ & $\begin{array}{c}\text { Baik } \\
(76-100 \%)\end{array}$ & \\
\hline 2014 & 0 & 5 & 4 & $9(2.3 \%)$ \\
\hline 2015 & 1 & 14 & 1 & $16(4 \%)$ \\
\hline 2016 & 0 & 27 & 8 & $\begin{array}{c}35 \\
(8.8 \%)\end{array}$ \\
2017 & 1 & 133 & 41 & $\begin{array}{c}175 \\
(44.2 \%)\end{array}$ \\
& & & &
\end{tabular}




\begin{tabular}{|c|c|c|c|c|}
\hline 2018 & 0 & 59 & 20 & 79 \\
\hline 2019 & 0 & 56 & 26 & 82 \\
\hline Total & 2 & 294 & 100 & $\begin{array}{c}396 \\
(100 \%)\end{array}$ \\
\hline
\end{tabular}

Berdasarkan Tabel 4.6 angkatan 2014 memiliki pengetahuan kurang sebanyak 0 orang, hal ini dapat terjadi karena angkatan 2014 telah mengetahui tentang sunscreen. Angkatan 2015 memiliki pengetahuan kurang sebanyak 1 orang, hal ini dapat terjadi dari 16 responden sebanyak 1 orang yang menjawab kuesioner kurang tepat karena kurang mencari tahu tentang sunscreen sehingga pengetahuan yang dimiliki masih kurang. Angkatan 2016 memiliki pengetahuan kurang sebanyak 0 orang, hal ini dapat terjadi karena angkatan 2016 telah mengetahui tentang sunscreen dimana angkatan 2016 menjawab pertanyaan kuesioner dengan tepat karena lebih sering mencari tahu tentang sunscreen. Angkatan 2017 memiliki pengetahuan kurang sebanyak 1 orang dari 175 orang, hal ini dapat terjadi karena sebanyak 1 orang masih kurang mencari tahu tentang sunscreen sehingga pertanyaan kuesioner tidak dijawab dengan tepat. Angkatan 2018 memiliki pengetahuan kurang sebanyak 0 orang, hal ini dapat terjadi karena angkatan 2018 telah mengetahui tentang sunscreen dan lebih sering mencari informasi tentang sunscreen. Angkatan 2019 memiliki pengetahuan kurang sebanyak 0 orang, hal ini dapat terjadi karena angkatan 2019 telah mengetahui tentang sunscreen. Untuk kategori cukup angkatan 2017 memiliki responden paling banyak yang berpengetahuan cukup sebanyak 133 orang, hal ini dapat terjadi karena angkatan 2017 lebih sering mencari informasi mengenai sunscreen baik melalui media sosial maupun pengetahuan yang dimiliki dan angkatan 2017 merupakan responden paling banyak yaitu 175 orang karena link kuesioner yang tersebar paling banyak pada angkatan 2017 sehingga merupakan responden terbanyak. Angkatan selanjutnya yang memiliki pengetahuan cukup yaitu angkatan 2018 sebanyak 59 orang, hal ini dapat terjadi karena angkatan 2018 juga lebih sering mencari tahu informasi tentang sunscreen sehingga memahami pertanyaan kuesioner. Angkatan 2019 yang memiliki pengetahuan cukup sebanyak 56 orang, hal ini dapat terjadi karena angkatan 2019 juga telah mengetahui tentang sunscreen dimana angkatan 2019 sering mencari tahu tentang sunscreen. Angkatan 2016 yang memiliki pengetahuan cukup sebanyak 27 orang, hal ini dapat terjadi karena dari 35 orang hanya sebanyak 27 orang yang lebih sering mencari tahu tentang sunscreen sehingga pertanyaan dari kuesioner bisa dijawab dengan tepat. Angkatan 2015 memiliki pengetahuan cukup sebanyak 14 orang, hal ini juga dapat terjadi karena pada angkatan 2015 dari 16 responden hanya 14 orang yang menjawab pertanyaan kuesioner dengan tepat. Angkatan 2014 yang memiliki pengetahuan cukup sebanyak 5 orang, hal ini dapat terjadi karena responden pada penelitian ini paling sedikit sebanyak 9 orang, sehingga yang memiliki pengetahuan cukup hanya 5 orang, karena berdasarkan pertanyaan kuesioner yang menjawab dengan tepat sebanyak 5 orang. Untuk kategori baik angkatan 2017 memiliki responden paling banyak yang berpengetahuan baik dibandingkan angkatan lainnya yaitu sebanyak 41 orang, hal ini dapat terjadi karena angkatan 2017 lebih sering mencari tahu tentang sunscreen, sehingga 
pengetahuan yang dimiliki lebih baik lagi. Angkatan 2019 memiliki pengetahuan baik sebanyak 26 orang, hal ini dapat terjadi karena angkatan 2019 juga lebih sering mencari tahu tentang sunscreen sehingga pengetahuan yang dimiliki lebih baik lagi. Angkatan 2018 memiliki pengetahuan baik sebanyak 20 orang dari 79 orang, hal ini dapat terjadi karena angkatan 2018 sebanyak 20 orang telah mengetahui tentang sunscreen dimana berdasarkan jawaban kuesioner sebanyak 20 orang menjawab dengan tepat. Angkatan 2016 memiliki pengetahuan baik sebanyak 8 orang dari 35 orang, hal ini dapat terjadi karena sebanyak 8 orang lebih sering mencari tahu informasi mengenai sunscreen sehingga mampu menjawab dengan tepat pertanyaan kuesioner yang telah dibagikan. Angkatan 2015 memiliki pengetahuan baik sebanyak 1 orang, hal ini dapat terjadi karena dari 16 orang hanya 1 orang yang sering mencari tahu tentang sunscreen sehingga yang berpengetahuan baik hanya 1 orang. Angkatan 2014 yang memiliki pengetahuan baik sebanyak 4 orang dari 9 orang, hal ini juga dapat terjadi karena sebanyak 4 orang lebih sering mencari tahu informasi mengenai sunscreen sehingga pengetahuan yang dimiliki lebih baik lagi dan angkatan 2014 memiliki responden paling sedikit karena berdasarkan link kuesioner yang telah disebar yang hanya 9 orang yang mengisi kuesioner.

Maka dapat disimpulkan bahwa tingkat pengetahuan mahasiswa di Universitas Tadulako cenderung memiliki tingkat pengetahuan dengan kategori cukup jika dilihat dari segi usia, jenis kelamin dan angkatan. Hal ini berbanding terbalik berdasarkan hasil penelitian (Wadoe \& Wadoe,
2015). Hal ini menunjukkan bahwa pengetahuan responden tentang sunscreen masih sangat rendah, dari 130 orang responden yang mengisi kuesioner, 7 orang memiliki pengetahuan kurang baik, 13 orang yang memiliki pengetahuan baik, dan sebanyak 110 orang yang memiliki pengetahuan tingkat menengah. Ratarata tingkat pengetahuan tentang sunscreen di antara 130 responden adalah 7,3 jauh dibawah nilai 32 yang merupakan tingkat pengetahuan tertinggi dalam survey. Dari 130 responden, sebanyak 53 responden memiliki pengetahuan di atas rata-rata, sedangkan 67 responden memiliki tingkat pengetahuan dibawah rata-rata. Survei tersebut tidak banyak mengetahui tentang sunscreen.

\section{$f$. Pengetahuan mahasiswa Universitas Tadulako tentang penggunaan Sunscreen}

1. Persentase rata-rata tingkat pengetahuan tentang sunscreen

\begin{tabular}{lcc}
\hline $\begin{array}{l}\text { No } \\
\mathrm{N}\end{array}$ & \multicolumn{2}{c}{$\begin{array}{c}\text { Rata-rata jawaban } \\
\text { responden (\%) }\end{array}$} \\
\hline $\begin{array}{l}\text { 1 Mahasiswa Universitas } \\
\text { Tadulako } 396\end{array}$ & Benar & Salah \\
\hline $\mathbf{1 7 , 7 8 \%}$ & & $\mathbf{8 2 , 2 2 \%}$ \\
\hline
\end{tabular}

Berdasarkan Tabel 4.8 bahwa dari 396 responden penelitian, diketahui bahwa persentase rata-rata mahasiswa yang menjawab benar yaitu sebanyak $82,22 \%$ dan menjawab salah yaitu $17,78 \%$. Menurut (Nursalam, 2016) dibagi menjadi 3 kategori, jika persentase jawaban benar pada kisaran 76-100\% berarti klasifikasi baik; jika persentase jawaban benar pada kisaran 56-75\% maka klasifikasi sudah cukup; jika $<56 \%$, kemudian diklasifikasikan sebagai buruk atau kurang baik. Berdasarkan persentase jawaban benar responden untuk variabel 
pengetahuan sunscreen dapat disimpulkan responden memiliki pengetahuan baik.

g. Faktor-faktor yang berhubungan dengan pengetahuan penggunaan sunscreen pada mahasiswa di Universitas Tadulako

1. Hubungan usia dengan pengetahuan penggunaan sunscreen

\begin{tabular}{|c|c|c|c|c|c|c|}
\hline \multirow[t]{2}{*}{ Usia } & \multicolumn{3}{|c|}{$\begin{array}{c}\text { Pengetahuan } \\
\text { penggunaan sunscreen }\end{array}$} & \multirow[t]{2}{*}{$\begin{array}{c}\text { Total } \\
\text { Responden }\end{array}$} & \multirow[t]{2}{*}{$\alpha$} & \multirow[t]{2}{*}{$\begin{array}{c}p- \\
\text { value }\end{array}$} \\
\hline & Kurar & Cukup & Baik & & & \\
\hline $\begin{array}{r}18- \\
20 \\
\end{array}$ & 0 & 133 & 54 & $\begin{array}{l}187 \\
(47.2 \%) \\
\end{array}$ & & \\
\hline $\begin{array}{l}21- \\
23 \\
\end{array}$ & 2 & 159 & 46 & $\begin{array}{l}207 \\
(52.3 \%) \\
\end{array}$ & 0,05 & 0,323 \\
\hline $\begin{array}{r}24- \\
26 \\
\end{array}$ & 0 & 2 & 0 & $2(0.5 \%)$ & & \\
\hline Total & 2 & 294 & 100 & $\begin{array}{c}396 \\
(100 \%)\end{array}$ & & \\
\hline
\end{tabular}

Berdasarkan tabel diatas usia 1820 memiliki pengetahun kurang sebanyak 0 orang $(0 \%)$, pengetahuan cukup sebanyak 133 orang $(33,6 \%)$ dan pengetahuan baik sebanyak 54 orang (13,7\%)dengan jumlah responden sebanyak 187 orang $(47,2 \%)$, usia 21 23 memiliki pengetahuan kurang sebanyak 2 orang $(0,5 \%)$, pengetahuan cukup sebanyak 159 orang $(40,1 \%)$ dan pengetahuan baik 46 orang $(11,6 \%)$ dengan jumlah responden sebanyak 207 orang (52,3\%). Usia 24-26 memiliki pengetahuan kurang sebanyak 0 orang (0\%), pengetahuan cukup sebanyak 2 orang $(0,5 \%)$, dan pengetahuan baik sebanyak 0 orang $(0 \%)$ dengan jumlah responden sebanyak 2 orang $(0,5 \%)$. Total keseluruhan jumlah responden berdasarkan usia 18-20, usia 21-23 dan usia 24-26 memiliki kategori kurang sebanyak 2 orang $(0,5 \%)$ karena berdasarkan pertanyaan kuesioner sebanyak 2 orang yang menjawab kurang dimana kategori kurang berkisar $<56 \%$. Kemudian berdasarkan kategori cukup sebanyak 294 orang (74,2\%) karena berdasarkan pertanyaan kuesioner sebanyak 294 orang yang menjawab cukup dimana kategori cukup berkisar 56\% - 75\%. Kemudian berdasarkan kategori baik sebanyak 100 $(25,2 \%)$ orang yang menjawab baik dimana kategori baik berkisar $76 \%$ $100 \%$.

Dari penelitian yang telah dilakukan, berdasarkan hasil analisis data secara statistik menggunakan uji chi-square didapatkan nilai p-value $0,323>0,05$ sehingga dapat disimpulkan bahwa gagal menolak $H_{0}$ yang berarti tidak ada hubungan antar usia dengan pengetahuan penggunaan sunscreenpada mahasiswa di Universitas Tadulako karena nilai $p$ value $0,323>0,05$. Hal ini sesuai dengan literatur menurut (Mubarak, 2011) ada beberapa faktor yang mempengaruhi pengetahuan seseorang, salah satunya adalah usia, usia akan mempengaruhi pemahaman, gaya berpikir seseorang akan semakin berkembang sehingga pengetahuan yang diperoleh semakin baik. Akan tetapi berdasarkan hasil penelitian yang telah dilakukan pada mahasiswa di Universitas Tadulako didapatkan hasil bahwa 187 mahasiswa yang berusia 1820 tahun, 207 mahasiswa yang berusia 21-23 tahun dan 2 mahasiswa yang berusia 24-26 tahun rata-rata memiliki tingkat pengetahuan yang tergolong baik yaitu dengan total 294 secara keseluruhan dari 396 responden dan berjumlah jauh lebih banyak dibanding mahasiswa yang tingkat pengetahuannya rendah. Hal ini menunjukkan bahwa di Universitas Tadulako tingkat pengetahuan mahasiswa tentang sunscreen tidak berhubungan dengan usia mahasiswa. Hal tersebut dapat terjadi jika mahasiswa yang berusia lebih muda jauh lebih sering mencari informasi tentang penggunaan sunscreen, memiliki lingkungan yang mendukung 
atau mempengaruhi seseorang lebih ingin mengetahui tentang penggunaan sunscreen dan hal itu juga merupakan faktor yang mempengaruhi pengetahuan seseorang.

2. Hubungan jenis kelamin dengan pengetahuan penggunaan sunscreen

\begin{tabular}{|c|c|c|c|c|c|c|}
\hline \multirow[t]{2}{*}{$\begin{array}{l}\text { Jenis } \\
\text { Kelamin }\end{array}$} & \multicolumn{3}{|c|}{$\begin{array}{c}\text { Pengetahuan penggunaan } \\
\text { sunscreen }\end{array}$} & \multirow[t]{2}{*}{$\begin{array}{c}\text { Total } \\
\text { Responden }\end{array}$} & \multirow[t]{2}{*}{$\alpha$} & \multirow[t]{2}{*}{$\begin{array}{c}p- \\
\text { value }\end{array}$} \\
\hline & Kurang & Cukup & Baik & & & \\
\hline $\begin{array}{l}\text { Laki- } \\
\text { Laki }\end{array}$ & 2 & 73 & 36 & $111(28 \%)$ & \multirow[t]{2}{*}{0,05} & \multirow[t]{2}{*}{0,008} \\
\hline $\begin{array}{c}\text { Peremp } \\
\text { an }\end{array}$ & o & 221 & 64 & $285(72 \%)$ & & \\
\hline Total & 2 & 294 & 100 & $\begin{array}{c}396 \\
(100 \%)\end{array}$ & & \\
\hline
\end{tabular}

Berdasarkan Tabel 4.10 jenis kelamin laki-laki memiliki pengetahuan kurang sebanyak 2 orang $(0,5 \%)$, pengetahuan cukup sebanyak 73 orang $(18,4 \%)$ dan pengetahuan baik sebanyak 36 orang $(9,2 \%)$ dengan jumlah responden sebanyak 111 orang (28\%), sedangkan jenis kelamin perempuan memiliki pengetahuan kurang sebanyak 0 orang $(0 \%)$, pengetahuan cukup sebanyak 221 orang $(55,8 \%)$ dan pengetahuan baik sebanyak 64 orang $(16.1 \%)$ dengan jumlah responden sebanyak 285 orang (72\%). Total keseluruhan jumlah responden berdasarkan jenis kelamin laki-laki dan perempuan memiliki kategori pengetahuan kurang sebanyak 2 orang $(0,5 \%)$ karena berdasarkan pertanyaan kuesioner sebanyak 2 orang yang menjawab kurang dimana kategori kurang berkisar $<56 \%$. Pengetahuan cukup sebanyak 294 orang $(74,2 \%)$ karena berdasarkan pertanyaan kuesioner sebanyak 294 orang yang menjawab kurang. Pengetahuan baik sebanyak 100 orang $(25,3 \%)$ karena berdasarkan pertanyaan kuesioner sebanyak 100 orang yang menjawab baik.

Dari penelitian yang telah dilakukan, berdasarkan hasil analisis data secara statistik menggunakan uji chi- square, didapatkan nilai $p$-value $0,008<$ 0,05 sehingga dapat disimpulkan bahwa tolak $H_{0}$ yang berarti ada hubungan antar jenis kelamin dengan pengetahuan penggunaan sunscreen pada mahasiswa di Universitas Tadulako karena nilai $p$ value $0,008<0,05$.pada mahasiswa yang berjenis kelamin laki-laki sebanyak 111 orang dan perempuan sebanyak 285 orang, pengetahuan penggunaan pada mahasiswa laki-laki masih dalam kategori kurang hal ini terjadi karena mahasiswa laki-laki masih kurang mengetahui tentang penggunaan sunscreen sedangkan mahasiswa perempuan memiliki tingkat pengetahuan yang bagus yaitu berada ditingkat pengetahuan cukup dibandingkan lakilaki, hal ini dapat terjadi karena mahasiswa yang berjenis kelamin perempuan telah mengetahui penggunaan sunscreen itu sendiri. Hal ini sesuai dengan penelitian disalah satu Universitas di Palestina mengenai pengetahuan dan perilaku penggunaan sunscreen menunjukkan bahwa dari 250 responden hanya $118(47,2 \%)$ responden yang menggunakan sunscreen serta pengunaan pada laki-laki hanya sekitar $14,4 \%$.

3. Hubungan angkatan dengan pengetahuan penggunaan sunscreen

\begin{tabular}{|c|c|c|c|c|c|c|}
\hline Angkatan & Pengeta & $\begin{array}{l}\text { Ian pengg } \\
\text { nscreen }\end{array}$ & naan & $\begin{array}{c}\text { Total } \\
\text { Responden }\end{array}$ & $\alpha$ & $\begin{array}{c}p- \\
\text { value }\end{array}$ \\
\hline & Kurang & Cukup & Baik & & \multirow{7}{*}{0,05} & \multirow{7}{*}{0,054} \\
\hline 2014 & 0 & 5 & 4 & $9(2.3 \%)$ & & \\
\hline 2015 & 1 & 14 & 1 & $16(4 \%)$ & & \\
\hline 2016 & 0 & 27 & 8 & $35(8.8 \%)$ & & \\
\hline 2017 & 1 & 133 & 41 & $175(44.2 \%)$ & & \\
\hline 2018 & 0 & 59 & 20 & $79(20 \%)$ & & \\
\hline 2019 & 0 & 56 & 26 & $82(20.7 \%)$ & & \\
\hline Total & 2 & 294 & 100 & $\begin{array}{c}396 \\
(100 \%)\end{array}$ & & \\
\hline
\end{tabular}

Berdasarkan Tabel diatas angkatan 2014 memiliki pengetahuan kurang sebanyak 0 orang (0\%), pengetahuan cukup sebanyak 5 orang $(1,26 \%)$ dan pengetahuan baik sebanyak 4 orang $(1 \%)$ dengan jumlah responden sebanyak 9 
orang (2,3\%). Angkatan 2015 memiliki pengetahuan kurang sebanyak 1 orang $(0,25 \%)$, pengetahuan cukup sebanyak 14 orang $(3,54 \%)$ dan pengetahuan baik sebanyak 1 orang $(0,25 \%)$ dengan jumlah responden sebanyak 16 orang (4\%). Angkatan 2016 memiliki pengetahuan kurang sebanyak 0 orang (0\%), pengetahuan cukup sebanyak 27 orang (6.8\%) dan pengetahuan baik sebanyak 8 orang (2\%) dengan jumlah responden sebanyak 35 orang $(8.8 \%)$. Angkatan 2017 memiliki pengetahuan kurang sebanyak 1 orang $(0 \%)$, pengetahuan cukup sebanyak 133 orang $(33,6 \%)$ dan pengetahuan baik 41 orang $(10,4 \%)$ dengan jumlah responden sebanyak 175 orang (44,2\%). Angkatan 2018 memiliki pengetahuan kurang sebanyak 0 orang (0\%), pengetahuan cukup sebanyak 59 orang $(14,9 \%)$ dan pengetahuan baik sebanyak 20 orang $(5,1 \%)$ dengan jumlah responden sebanyak 79 orang (20\%). Angkatan 2019 memiliki pengetahuan kurang sebanyak 0 orang (0\%), pengetahuan cukup sebanyak 56 orang $(14,1 \%)$ dan pengetahuan baik sebanyak 26 orang $(6,7 \%)$ dengan jumlah responden sebanyak 82 orang $(20,7 \%)$.Total keseluruhan responden berdasarkan angkatan 2014, 2015, 2016, 2017, 2018 dan 2019 memiliki pengetahuan kurang sebanyak 2 orang $(0,5 \%)$ karena berdasarkan pertanyaan kuesioner sebanyak 2 orang yang menjawab kurang dimana kategori kurang berkisar $<56 \%$. Pengetahuan cukup sebanyak 294 orang (74,2\%) karena berdasarkan pertanyaan kuesioner sebanyak 294 orang yang menjawab kurang. Pengetahuan baik sebanyak 100 orang $(25,3 \%)$ karena berdasarkan pertanyaan kuesioner sebanyak 100 orang yang menjawab baik.

Dari penelitian yang telah dilakukan, berdasarkan hasil analisis data secara statistik menggunakan uji chisquare, didapatkan nilai $p$-value $0,054>$ 0,05 sehingga dapat disimpulkan bahwa gagal tolak $H_{0}$ yang berarti tidak ada hubungan antar tahun angkatan masuk dengan pengetahuan penggunaan sunscreen pada mahasiswa di Universitas Tadulako karena nilai p-value 0,054> 0,05 . Hal ini berbanding terbalik dengan literatur menurut (Wawan, A., \& Dewi, 2011) ada beberapa faktor yang mempengaruhi pengetahuan seseprang, salah satunya adalah pendidikan. Semakin tinggi latar belakang pendidikan seseorang maka semakin mudah pula orang tersebut untuk menerima dan mencari informasi dari berbagai sumber, sehingga meningkatkan kualitas hidup dan informasi yang dimilikinya. Tetapi berdasarkan hasil penelitian angkatan yang paling banyak yaitu angkatan 2017, hal ini disebabkan karena angkatan 2017 lebih sering mencari informasi megenai sunscreen dan angkatan 2017 merupakan responden paling banyak karena lebih banyaknya responden angkatan 2017 yang mengisi kuesioner sedangkan angkatan 2016-2014 merupakan responden paling sedikit hanya sekitar 60 orang, hal ini dapat terjadinya karena kurangnya dari angkatan tersebut yang mengisi kuesioner.

\section{Kesimpulan}

Pertama tingkat pengetahuan mahasiswa Universitas Tadulako tentang penggunaan sunscreen memiliki tingkat pengetahuan dengan kategori baik jika dilihat dari rata-rata jumlah persentase jawaban benar $82,22 \%$.

Kedua tingkat pengetahuan penggunaan sunscreen berdasarkan segi usia, jenis kelamin dan angkatan memiliki tingkat pengetahuan dengan kategori cukup jika dilihat dari persentase rata-rata $74,2 \%$. 
Ketiga faktor-faktor yang berhubungan dengan pengetahuan penggunaan sunscreen adalah variable jenis kelamin, dapat dilihat dari hasil uji chi-square dengan nilai $p$-value $0,008<0,05$ dapat dikatakan tolak $\mathrm{H}_{0}$ yang berarti ada hubungan antar jenis kelamin dengan pengetahuan penggunaan sunscreen pada mahasiswa Universitas Tadulako.

\section{BIBLIOGRAFI}

Gontor, U. D. (2016). Pelindung Telinga Dengan Penggunaannya Pada Pekerja Di Pt . X Ragil Retnaningsih Related Knowledge And Attitudes Of Ear Protective Equipment Usage On Workers Of Pt.X Abstract Belakang Tersebut, > $90 \mathrm{Db}$, Sedangkan Nilai Ambang Batas. 1(1). Google Scholar

Ignas. (2014). Analisis Data Penelitian Dengan Spss 22. Wahana Komputer. Google Scholar

Isabela, E. (2010). Studi Tentang Identitas Mahasiswa Di Yogyakarta Melalui Cara Berpakaian. Google Scholar

Kementrian Kesehatan Republik Indonesia. (2014). Kesehatan Indonesia. Google Scholar

Mubarak, W. (2011). Promosi Kesehatan Masyarakat Untuk Kebidanan. Salemba Medika. Google Scholar

Muda, T. D. (2014). Analisis Pengaruh Kualitas Pelayanan Dan Kualitas Tenaga Medis Terhadap Kepuasan Pasien Rawat Inap Di Rsud Kabupaten Batang. Universitas Di Ponegoro. Google Scholar

Mumtazah, E. F., Salsabila, S., Lestari, E. S., Rohmatin, A. K., Ismi, A. N., Rahmah, H. A., Mugiarto, D., Daryanto, I., Billah, M., Salim, O. S., Damaris, R., Astra, A. D., Zainudin, L. B., Noorrizka, G., \& Ahmad, V. (2020). Pengetahuan
Mengenai Sunscreen Dan Bahaya Paparan Sinar Matahari Serta Perilaku Mahasiswa Teknik Sipil Terhadap Penggunaan Sunscreen. 7(2), 63-68. Google Scholar

Notoatmodjo. (2012). Promosi Kesehatan Dan Perilaku Kesehatan. Pt Rineka Cipta. Google Scholar

Nursalam. (2016). Metodologi Penelitian Ilmu Keperawatan: Pendekatan. Salemba Medika. Google Scholar

Pratiwi, S., Husni, P., Studi, P., Apoteker, P., Farmasi, F., \& Padjadjaran, U. (2017). Farmaka Farmaka. 15, 18-25. Google Scholar

Rossy Ardhia Pramesti. (2019). Gambaran Tingkat Pengetahuan Dan Sikap Mahasiswa Fakultas Kedokteran Universitas Islam Negeri Syarif Hidayatullah Jakarta Angkatan 2016 Terhadap Penggunaan Tabir Surya. Google Scholar

Rosyidi, V. A., Ummah, L., \& Kristiningrum, N. (2018). Optimasi Zink Oksida Dan Asam Malat Dalam Krim Tabir Surya Kombinasi Avobenzone Dan Octyl Methoxycinnamate Dengan Desain Faktorial ( Optimization Of Zinc Oxide And Malic Acid In Sunscreen Cream Combination Of Avobenzone And Octyl Methoxycinnamate With Fac. 6(3), 426432. Google Scholar

Suaskara.M.Si, D. I. B. M. (2016). Buletin Fisika. 1. Google Scholar

Wadoe, M., \& Wadoe, M. (2015). Penggunaan Dan Pengetahuan Sunscreen Pada. 6(1), 1-8. Google Scholar

Wawan, A., \& Dewi, M. (2011). Teori Dan Pengukuran Pengetahuan, Sikap Dan Perilaku Manusia. Nuha Medika. Google Scholar 
Ariska Pramesti Sagita Cahyani, Putri Aprilia Aini H, Ertien Rining Nawangsari

Copyright holder:

Nurfitriani, Amelia Rumi dan Asriana Sultan (2021)

First publication right:

Jurnal Health Sains

This article is licensed under:

(cc) (i) (9) 